\title{
Innlagnir á gjörgæslu eftir blaðnám og fleygskurði við lungnakrabbameini
}

Tómas Andri Axelsson¹,2 læknanemi, Martin Ingi Sigurðsson³ læknir, Ásgeir Alexandersson² læknir, Húnbogi Porsteinsson² læknir, Guð̋mundur Klemenzson ${ }^{3}$ læknir, Steinn Jónsson ${ }^{1,4}$ læknir, Tómas Guðbjartsson ${ }^{1,2}$ læknir

\section{ÁGRIP}

Inngangur: Eftir brjóstholsskurðaðgerð við lungnakrabbameini eru sjúklingar jafnan lagðir á vöknunardeild í nokkrar klukkustundir áður en peir flytjast á legudeild. Sumir parfnast pó innlagnar á gjörgæsludeild, ýmist í beinu framhaldi af aðgerð eða af vöknunar- eða legudeild. Tilgangur rannsóknarinnar var að kanna ástæður og áhættupætti fyrir gjörgæsluinnlögn eftir pessar aðgerðir.

Efniviður og aðferðir: Afturskyggn rannsókn á 252 sjúklingum sem gengust undir blaðnám, fleyg- eða geiraskurð vegna lungnakrabbameins á Landspítala 2001-2010. Upplýsingar fengust úr sjúkraskrám og voru sjúklingar sem lögðuust á gjörgæslu bornir saman við pá sem ekki lögðust pangað inn.

Niðurstöður: Alls lagðist 21 sjúklingur (8\%) á gjörgæsludeild og var miðgildi legutíma einn dagur (bil 1-68). Hjá 11 sjúklinganna (52\%) var innlögn rakin til vandamála í aðgerð, oftast lágs blóðprýstings eða blæđingar.
Tíu sjúklingar lögðust á gjörgæslu af legudeild $(n=4)$ eða vöknunardeild $(n=6)$ og voru ástæður innlagnar lágur blóðprýstingur $(n=4)$, hjarta- og/eða öndunarbilun $(n=4)$ og enduraðgerð vegna blæðingar $(n=2)$. Prír sjúklingar voru lagðir inn að nýju eftir útskrift af gjörgæslu. Meðalaldur gjörgæslusjúklinga var sex árum hærri en viðmiðunarhóps $(p=0,004)$ og peir höfðu oftar sögu um langvinna lungnateppu og kransæðasjúkdóm. Stærð æxlis, pTNM-stig, aðgerðarlengd og hlutfall sjúklinga með utanbastsdeyfingu voru sambærileg í hópunum. Rúmlega tveir priðju hópsins greindust með minniháttar fylgikvilla og tæplega helmingur alvarlega fylgikvilla, samanborið við $30 \%$ og $4 \%$ í viðmiðunarhópi.

Ályktun: Fáir sjúklingar parfnast innlagnar á gjörgæslu eftir skurðaðgerðir við lungnakrabbameini og pá oftast peir sem eru eldri og með sögu um hjarta- og lungnasjúkdóma. Í helmingi tilfella er innlögn á gjörgæslu í beinu framhaldi af aðgerð og endurinnlagnir pangað eru fátíðar.
Fyrirspurnir:

Tómas Guðbjartsson tomasgud@landspitali.is

Greinin barst: 8. nóvember 2011, sampykkt til birtingar: 23. apríl 2012

\section{Inngangur}

Á Íslandi greinast árlega um 150 einstaklingar með lungnakrabbamein og eru 125 peirra ekki smáfrumukrabbamein (non-small cell lung cancer). ${ }^{1}$ Skurðaðgerð kemur til greina hjá priðjungi pessara sjúklinga.,3 Blaðnám er algengasta aðgerðin og er gerð í $80 \%$ tilfella en sjúklingar með skerta lungnastarfsemi gangast stundum undir fleyg- eða geiraskurð. ${ }^{2}$ Loks getur brottnám heils lunga komið til greina hjá sjúklingum með stór og/eða miðlæg lungnaæxli. Dánartíðni er umtalsvert hærri eftir lungnabrottnám samanborið við minni aðgerðirnar og tíðni alvarlegra fylgikvilla á borð við hjarta- og öndunarbilun er allt að tvöfalt hærri. ${ }^{4,5}$

Vöktun sjúklinga eftir lungnaskurðaðgerðir er vandasöm, enda eru margir peirra með sjúkdóm í æðakerfi eða teppusjúkdóm í lungum vegna reykinga. ${ }^{4,6}$ Einnig eru verkir frá brjóstholsskurði (thoracotomy) oft vandamál.7 Auk hefðbundinna verkjalyfja er oftast notast við úttaugadeyfingar á borð við millirifja- eða taugarótardeyfingu (intercostal block, paravertebral block) en á síðustu árum í vaxandi mæli utanbastdeyfingu (thoracic epidural anaesthesia). . $^{8}$

Allir sjúklingar sem gangast undir lungnabrottnám eru vaktaðir á gjörgæslu í að minnsta kosti sólarhring. Eftir blaðnám, fleyg- eða geiraskurð eru sjúklingar hins vegar vaktaðir á vöknunardeild í 4-6 klukkustundir en peir síðan fluttir á legudeild hjarta- og lungnaskurðdeildar. Komi upp vandamál í aðgerð, á vöknunardeild eða legudeild, eru sjúklingarnir jafnan lagðir inn á gjörgæsludeild. Par er hægt að fylgjast náið með blóðrás (invasive hemodynamic monitoring) og veita sérhæfða gjörgæslumeðferð með blóðprýstingshækkandi lyfjum eða öndunarvél. Gjörgæslupláss eru jafnan af skornum skammti og talsvert dýrari en pláss á legudeild. Pví er mikilvægt að vita hvaða sjúklingar gætu purft á gjörgæslumeðferð að halda, ekki síst eftir algengar aðgerðir eins og brjóstholsskurð vegna lungnakrabbameins. Á Landspítala hefur vantað upplýsingar um hlutfall sjúklinga sem parfnast gjörgæslumeðferðar eftir lungnaskurðaðgerðir vegna lungnakrabbameins (lungnabrottnámsaðgerðir undanskildar) og sömuleiðis afdrif peirra.

Tilgangur pessarar rannsóknar var að skoða ástæður fyrir gjörgæsluinnlögn hjá pessum sjúklingum og afdrif peirra fyrstu mánuðina eftir aðgerð á 10 ára tímabili. Einnig var reynt að skilgreina áhættupætti fyrir gjörgæsluinnlögn í kjölfar aðgerðanna.

\section{Efniviður og aðferðir}

Rannsóknin var afturskyggn og náði til sjúklinga sem gengust undir blaðnám, fleyg- eða geiraskurð á Landspítala við lungnakrabbameini (ekki smáfrumukrabbameini) frá 1. janúar 2001 til 31. desember 2010. Sjúklingum sem gengust undir lungnabrottnám var sleppt, par sem peir eru alltaf vaktaðir á gjörgæsludeild. Í rannsóknarhópi voru 252 sjúklingar; 21 sem lagðist á 


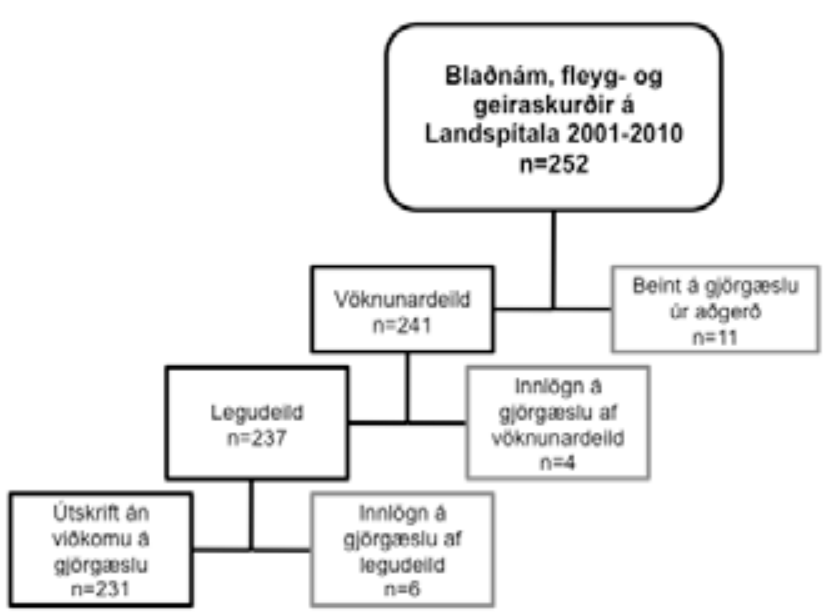

Mynd 1. Flæðirit sem sýnir rannsóknarúrtakið (grálitaðir kassar) og viðmiðunarhóp.

gjörgæsludeild en hinir 231 mynduðu viðmiðunarhóp. Hóparnir voru bornir saman og reynt að skilgreina áhættupætti fyrir innlögn á gjörgæsludeild. Mynd 1 sýnir flæðirit yfir rannsóknar- og viðmiðunarhóp.

Upplýsingar um sjúklinga fengust úr gagnagrunni hjartaog lungnaskurðdeildar Landspítala en í hann eru skráðar allar lungnaskurðaðgerðir sem framkvæmdar hafa verið á Landspítala frá árinu 1986 og fram til ársloka 2010. Í gagnagrunninum eru meðal annars upplýsingar um einkenni við greiningu, áhættupætti hjarta- og æðasjúkdóma, ástand sjúklings fyrir aðgerð, fylgikvilla í og eftir aðgerð, auk heildarlegutíma á spítala. Sjúkraskrár sjúklinga sem lögðust á gjörgæsludeild voru kannaðar sérstaklega, par á meðal dagálar af gjörgæsludeild og svæfingaskýrslur. Einnig var skráð tegund verkjastillingar, auk innlagnarástæðu og meðferð á gjörgæsludeild. Loks voru skráð vandamál sem komu upp í kjölfar aðgerðar og afdrif og lifun sjúklinganna könnuð.

Áhætta sjúklinga fyrir aðgerð var metin af læknum svæfingaog gjörgæsludeildar samkvæmt ASA-flokkunarkerfinu (American Society of Anesthesiologists). ${ }^{10}$ Útbreiðsla lungnakrabbameins var stiguð samkvæmt endurbættu TNM-stigunarkerfi WHO frá 200911 og var skráð bæði vefjagerð frumæxlis og mesta pvermál pess.

Sex skurðlæknar framkvæmdu aðgerðirnar og voru sjúklingarnir svæfðir á hefðbundinn hátt og barkapræddir með tvíopa berkjurennu (double lumen tube) svo unnt væri að fella saman pað lunga sem átt var við í aðgerðinni. Hjá flestum sjúklingum var lagður utanbastdeyfileggur fyrir aðgerð en hjá einstaka sjúklingum var beitt millirifja- eða taugarótardeyfingu í stað utanbastdeyfingar. Framan af voru flestar aðgerðanna framkvæmdar með aftari/hliðar brjóstholsskurði (posterolateral thoracotomy), par sem sjúklingurinn liggur í $90^{\circ}$ hliðarlegu, en upp úr 2005 var oftar gerður fremri/hliðar brjóstholsskurður (anterolateral thoracotomy) með sjúkling $145^{\circ}$ hliðarlegu. Við blaðnám var heftað eða saumað fyrir slag- og bláæðar, auk berkju til pess blaðs sem átti að fjarlægja. Við fleyg- og geiraskurði var einnig notuð heftibyssa. Í lok aðgerðanna var jafnan komið fyrir tveimur brjóstholskerum og peir fjarlægðir pegar loftleki hafði stöðvast og vökvamagn í peim var minna en $200 \mathrm{ml}$ á sólarhring.

Við tölfræðilega úrvinnslu voru notuð tölvuforritin Excel og R. Við marktækniútreikninga fyrir samfelldar breytur var notast við t-próf pegar breytan var normaldreifð en annars Mann-Whitney-
Tafla I. Innlagnarástæður og upplýsingar um sjúklinga.

\begin{tabular}{|c|c|c|c|c|}
\hline Aldur/kyn & $\begin{array}{l}\text { ASA - } \\
\text { flokkun }\end{array}$ & pTNM-stig & Ástæða fyrir innlögn & $\begin{array}{l}\text { Dagar á } \\
\text { gjörgæslu }\end{array}$ \\
\hline \multicolumn{5}{|c|}{ Sjúklingar ( $n=11$ ) sem lögðust á gjörgæsludeild beint eftir aðgerð } \\
\hline $79 / \mathrm{Kk}$ & 2 & $\| A$ & Eftirlit & 3 \\
\hline $73 / \mathrm{Kk}$ & 2 & IV & $\begin{array}{c}\text { Sár opnað að nýju } \\
\text { og annað lungnablað } \\
\text { fjarlægt }\end{array}$ & 68 \\
\hline $78 / \mathrm{Kk}$ & 3 & $\mathrm{IA}$ & Lágur líkamshiti & 1 \\
\hline $73 / \mathrm{Kk}$ & 3 & IV & Lágur blóðprýstingur & 1 \\
\hline $85 / \mathrm{Kvk}$ & 2 & IIA & Blæðing í aðgerð & 1 \\
\hline $71 / \mathrm{Kk}$ & 3 & IIB & Blæðing í aðgerð & 64 \\
\hline $56 / \mathrm{Kk}$ & 3 & IB & Erfið barkapræðing & 1 \\
\hline $77 / \mathrm{Kk}$ & 3 & IIB & Eftirlit & 1 \\
\hline $60 / \mathrm{Kk}$ & 4 & IA & Lágur blóðprýstingur & 1 \\
\hline 73/Kvk & 2 & IIIA & Lágur blóðprýstingur & 1 \\
\hline $79 / \mathrm{Kk}$ & 3 & IA & Lágur blóðprýstingur & 11 \\
\hline \multicolumn{5}{|c|}{ Sjúklingar ( $n=10$ ) sem lögðust á gjörgæsludeild af vöknunardeild eða legudeild } \\
\hline $77 / \mathrm{Kk}$ & 4 & IB & $\begin{array}{c}\text { Enduraðgerð vegna } \\
\text { blæðingar }\end{array}$ & 1 \\
\hline $71 / \mathrm{Kk}$ & 3 & IA & $\begin{array}{l}\text { Enduraðgerð vegna } \\
\text { blæðingar }\end{array}$ & 1 \\
\hline $80 / \mathrm{Kvk}$ & 3 & IB & $\begin{array}{c}\text { Hjarta- og } \\
\text { öndunarbilun }\end{array}$ & 16 \\
\hline $59 / \mathrm{Kvk}$ & 3 & IB & Lágur blóðprýstingur & 1 \\
\hline $84 / \mathrm{Kvk}$ & 3 & $\| \mathrm{A}$ & Hjartabilun & 2 \\
\hline $74 / \mathrm{Kvk}$ & 3 & IA & Lágur blóðprýstingur & 1 \\
\hline $76 / \mathrm{Kk}$ & 3 & $\| \mathrm{A}$ & Lágur blóðprýstingur & 1 \\
\hline $79 / \mathrm{Kk}$ & 3 & IA & Öndunarbilun & 13 \\
\hline $62 / \mathrm{Kvk}$ & 3 & IIIA & Öndunarbilun & 4 \\
\hline $78 / \mathrm{Kvk}$ & 3 & IA & Lágur blóðprýstingur & 4 \\
\hline
\end{tabular}

próf. Pegar tvær flokkabreytur voru bornar saman var notast við kí-kvaðrat og Fisher exact-próf. Einnig var notað Kruskal Wallispróf til að bera saman meðaltöl samfelldra breyta sem ekki voru normaldreifðar eftir fleiri en tveimur flokkum. Gerð var fjölpátta lógistísk aðhvarfsgreining (multiple logistic regression) á áhættupáttum gjörgæsluinnlagnar. Inn í upphaflega líkanið voru teknar pær breytur sem skráðar voru fyrir aðgerð og tengjast verri útkomu, auk lýðfræðilegra breyta (aldur, kyn, reykingar, aðgerðartegund, niðurstaða blástursprófs, tilviljunargreining, og tilvist langvinnrar lungnateppu, hjartsláttaróreglu eða kransæðasjúkdóms). Spágeta upphaflega líkansins var svo könnuð og breytur felldar út með „stepwise backwards“ aðferð par til endanlegt módel fékkst út. Marktækni miðast við p-gildi <0,05.

Öll tilskilin leyfi lágu fyrir áđur en rannsóknin hófst, meðal annars frá Persónu- og siðanefnd og frá framkvæmdastjóra lækninga á Landspítala.

\section{Niðurstödur}

Af 252 aðgerðum voru 223 blaðnám (88\%) og 29 (12\%) fleyg- eða geiraskurðir. Átta sjúklingar gengust undir tvær aðgerðir og var 
Tafla II. Klíniskar upplýsingar um sjúklinga, fjöldi (\%).

\begin{tabular}{|c|c|c|c|}
\hline & $\begin{array}{c}\text { Gjörgæsluhópur } \\
n=21\end{array}$ & $\begin{array}{l}\text { Viðmiðunarhópur } \\
\text { n=231 }\end{array}$ & $\mathrm{p}$-gildi \\
\hline Aldur & $74 \pm 8$ & $68 \pm 10$ & 0,004 \\
\hline Karlkyn & $13(62)$ & $111(48)$ & 0,32 \\
\hline Reykingasaga & $20(95)$ & $221(96)$ & 1 \\
\hline Langvinn lungnateppa & $11(52)$ & $67(29)$ & 0,049 \\
\hline Kransæðasjúkdómur & $11(52)$ & $67(29)$ & 0,049 \\
\hline $\begin{array}{l}\text { Saga um } \\
\text { hjartsláttartruflanir }\end{array}$ & $5(24)$ & $189(32)$ & 0,56 \\
\hline \multicolumn{4}{|l|}{ ASA-flokkun* } \\
\hline 1 & $0(0)$ & $2(1)$ & 1 \\
\hline 2 & $4(19)$ & $97(42)$ & 0,06 \\
\hline 3 & $15(71)$ & $125(54)$ & 0,17 \\
\hline 4 & $2(10)$ & $6(3)$ & 0,14 \\
\hline FEV1 $<75 \%$ af spáđu** & $5(24)$ & $56(24)$ & 0,83 \\
\hline FVC $<80 \%$ af spáðu $u^{\star \star \star}$ & $4(19)$ & $38(17)$ & 0,76 \\
\hline Stærð æxlis (cm) & $3.5 \pm 2.1$ & $2.8 \pm 1.3$ & 0,06 \\
\hline \multicolumn{4}{|l|}{ TMN-stig } \\
\hline 1 & $11(52)$ & $130(56)$ & 0,91 \\
\hline$\|$ & $6(29)$ & $61(26)$ & 0,83 \\
\hline III & $2(10)$ & $32(14)$ & 0,82 \\
\hline IV & $2(10)$ & $8(4)$ & 0,44 \\
\hline
\end{tabular}

${ }^{*}$ American society of anesthesiologists.

**Forced expiratory volume in 1 second. Öndunarmælingar vantar hjá einum sjúklingi viớmiðunarhópi.

***Forced vital capacity. Öndunarmælingar vantar hjá einum sjúklingi i viớmiðunarhópi.

heildarfjöldi sjúklinga pví 244. Meðalaldur peirra var $68 \pm 9$ ár (bil 42-89) og voru karlar 51\% hópsins.

Í 21 af 252 aðgerðum (8\%) purftu sjúklingarnir að leggjast inn á gjörgæsludeild, 10 á fyrri helmingi rannsóknartímabilsins og 11 á pví síðara $(\mathrm{p}=0,94)$.

Í töflu I sjást innlagnarástæður og upplýsingar um pá sjúklinga sem lögðust á gjörgæsludeild. Sjúklingar sem lögðust beint á gjörgæsludeild eftir aðgerð voru 11 talsins, en fjórir peirra voru fluttir pangað sofandi með barkarennu. Miðgildi legutíma á gjörgæsludeild hjá pessum sjúklingum var einn dagur (bil 1-68) og var algengasta ástæða fyrir innlögn lágur blóðprýstingur, eða hjá fjórum sjúklingum. Í tveimur tilfellum var ástæða innlagnar á gjörgæsludeild mikil blæðing í aðgerð (>1,5 L). Tveir sjúklingar voru hafðir til eftirlits en annar peirra var hjartabilaður vegna ósæðarlokuprengsla og hinn hafði háan blóðprýsting. Sex pessara sjúklinga purftu meðferð í öndunarvél og létust tveir peirra. Annar lést á gjörgæsludeild 12 dögum eftir aðgerð vegna lungnabólgu, en hann hafði útskrifast paðan á öðrum degi eftir aðgerð en var lagður inn að nýju daginn eftir. Hinn sjúklingurinn lést á legudeild 75 dögum eftir aðgerð, en hann purfti meðferð í öndunarvél í 58 sólarhringa og dánarorsök hans var kransæðastífla.

Fjórir sjúklingar lögðust á gjörgæsludeild af vöknunardeild og sex frá legudeild hjarta- og lungnaskurðdeildar. Ástæður fyrir innlögn pessara 10 sjúklinga voru lágur blóðprýstingur $(n=4)$, hjartaog/eða öndunarbilun $(n=4)$ og enduraðgerð vegna blæðingar $(\mathrm{n}=2)$. Miðgildi legutíma á gjörgæsludeild fyrir pessa 10 sjúklinga
Tafla III. Fylgikvillar eftir aðgerð og dánarhlutfall i báðum hópum, fjöldi (\%).

\begin{tabular}{|c|c|c|c|}
\hline Fylgikvillar & $\begin{array}{l}\text { Gjörgæslu- } \\
\text { hópur n=21 }\end{array}$ & $\begin{array}{l}\text { Viðmiðunar- } \\
\text { hópur } n=231\end{array}$ & p-gildi \\
\hline Minniháttar fylgikvillar & $15(71)$ & $69(30)$ & $<0,001$ \\
\hline Langvarandi loftleki (>7dagar) & $9(43)$ & $39(17)$ & 0,008 \\
\hline Gáttatif & $5(24)$ & $42(18)$ & 0,56 \\
\hline Lungnabólga & $8(38)$ & $17(7)$ & $<0,001$ \\
\hline Sárasýking & $1(5)$ & $6(3)$ & 0,46 \\
\hline Fleiðruholssýking & $0(0)$ & $2(1)$ & 1 \\
\hline Lömun á raddbandataug & $0(0)$ & $4(2)$ & 1 \\
\hline Alvarlegir fylgikvillar & $10(48)$ & $10(4)$ & $<0,001$ \\
\hline Andnauðarheilkenni (ARDS) & $6(29)$ & $0(0)$ & $<0,001$ \\
\hline Hjartabilun & $4(19)$ & $4(2)$ & 0,002 \\
\hline $\begin{array}{l}\text { Enduraðgerð vegna } \\
\text { blæðingar }\end{array}$ & $4(19)$ & $3(1)$ & 0,001 \\
\hline Hjartadrep & $1(5)$ & $3(1)$ & 0,3 \\
\hline Berkjufleiðrufistill & $0(0)$ & $0(0)$ & \\
\hline Efri holæðarheilkenni & $0(0)$ & $1(1)$ & 1 \\
\hline \multicolumn{4}{|l|}{ Látnir } \\
\hline$<30$ daga & $2(10)$ & $0(0)$ & 0,006 \\
\hline$<90$ daga & $3(14)$ & $1(1)$ & 0,002 \\
\hline
\end{tabular}

var 1,5 dagur (bil 1-16) en fjórir purftu meðferð í öndunarvél og lést einn peirra. Sá sjúklingur hafði útskrifast af gjörgæsludeild en lagst par inn að nýju prívegis og var meðhöndlaður samtals 9 sólarhringa i öndunarvél. Dánarorsök hans var öndunarbilun vegna lungnabólgu og nýrnabilunar.

Miðgildi heildarlegutíma á sjúkrahúsi var 9 dagar fyrir allan hópinn. Legutími gjörgæsluhópsins var 19 dagar en 9 dagar hjá viðmiðunarhópi $(\mathrm{p}<0,001)$. Níu sjúklingar $(43 \%)$ lágu lengur en sólarhring á gjörgæslu, par af 5 (24\%) lengur en viku. Lengsta samfellda lega á gjörgæsludeild var 68 dagar en sá sjúklingur útskrifaðist heim til sín 38 dögum eftir útskrift af gjörgæsludeild.

Prír sjúklingar lögðust aftur inn á gjörgæsludeild eftir útskrift paðan, einn í prígang og lést hann síðar á legudeild (sjá ofar). Annar sjúklingur var lagður aftur inn á gjörgæsludeild sama dag og sá priðji degi eftir útskrift af gjörgæsludeild og lést hann par. Allir höfðu pessir sjúklingar gengist undir blaðnám og voru ástæður endurinnlagnar á gjörgæsludeild lágur blóðprýstingur hjá tveimur og öndunarbilun hjá einum.

Í töflu II sést samanburður hópa. Sjúklingar í gjörgæsluhópi voru eldri og oftar með sögu um langvinna lungnateppu og kransæðasjúkdóm. Kynjahlutfall og niðurstöður öndunarmælinga voru hins vegar sambærilegar og langflestir sjúklinganna í báðum hópum höfðu sögu um reykingar. Ekki var heldur munur á ASAflokkun sjúklinga, stærð eða pTNM-stigun sjúkdómsins, aðgerðartíma, blæðingu í aðgerð eða hlutfalli sjúklinga sem fengu utanbastsdeyfingu (89\%).

Í töflu III sjást fylgikvillar eftir aðgerð í hópunum tveimur. Alls fengu 71\% gjörgæslusjúklinga minniháttar fylgikvilla borið saman við 30\% í viðmiðunarhópi ( $p<0,001)$. Algengustu fylgikvillarnir voru langvarandi loftleki, gáttatif og lungnabólga. Hlutfall gjörgæslusjúklinga sem fengu alvarlega fylgikvilla var einnig 
marktækt hærra, eða $48 \%$ borið saman við $4 \%$ í viðmiðunarhópi $(\mathrm{p}<0,001)$.

Gerð var fjölpátta aðhvarfsgreining á áhættupáttum innlagnar á gjörgæsludeild. Einungis voru notaðar breytur sem pekktar voru fyrir aðgerð. Inn í upphaflega líkanið voru teknar pær breytur sem skráðar voru fyrir aðgerð og tengjast verri útkomu, auk lýðfræðilegra breyta (aldur, kyn, reykingar, aðgerðartegund, niðurstaða blástursprófs, tilviljunargreining, og tilvist langvinnrar lungnateppu, hjartsláttaróreglu eða kransæðasjúkdóms). Hærri aldur (OR 1,07, 95\% ÖB 1,00-1,14, p=0,04) og saga um langvinna lungnateppu (OR 4,07, 95\% ÖB 1,14-11,50, p=0,01) reyndust sjálfstæðir áhættupættir gjörgæsluinnlagnar en í líkaninu var einnig leiðrétt fyrir tilviljunargreiningu (OR 2,57, 95\% ÖB 0,90-7,28, p=0,08) og hámarksútblástursmagni lungna (FVC, forced vital capacity) (OR $1,43,95 \%$ ÖB 0,78-2,60, $\mathrm{p}=0,25)$.

\section{Umræða}

Tíðni innlagna á gjörgæsludeild eftir lungnaskurðaðgerðir við lungnakrabbameini reyndist frekar lág (8\%) og breyttist lítið á peim 10 árum sem rannsóknin tók til. Lág tíðni gjörgæsluinnlagna er athyglisverð par sem margir pessara sjúklinga hafa langa reykingasögu og eru með alvarlegan teppusjúkdóm í lungum, auk hjarta- og æðasjúkdóma. Í tveimur nýlegum erlendum rannsóknum var tíðni gjörgæsluinnlagna 6-10\% en peim í báðum voru teknir með sjúklingar sem gengist höfðu undir lungnabrottnám. ${ }^{12,13}$

Annað sem torveldar samanburð við aðrar rannsóknir er að mismunandi er eftir stofnunum hvernig vöktun pessara sjúklinga er háttað. Einnig geta skilgreiningar á gjörgæsludeild, vöknunardeild og hágæsludeild verið misjafnar milli stofnana. Í rannsókn Okiror var hlutfall innlagna á gjörgæsludeild pó svipað, eða $7 \% .^{13}$ Hins vegar lágu sjúklingar í peirri rannsókn að miðgildi î prjá daga á gjörgæsludeild í stað eins í okkar rannsókn. Áður voru innlagnir á gjörgæsludeild eftir pessar aðgerðir mun algengari á Landspítala, eða 64\% á árunum 1994-1998. ${ }^{14}$ Ástæður fyrir pessari fækkun eru sennilega margpættar. Framfarir í svæfingum og verkjameðferð gætu hafa skipt máli, eins og aukin notkun utanbastsdeyfinga. Einnig gæti bætt tækni við skurðaðgerðirnar skýrt hluta fækkunarinnar, til dæmis aukin notkun fremri hliðarskurðar sem veldur minni verkjum en aftari hliðarskurður. ${ }^{15}$ Sennilega vega pó pyngra breyttar ábendingar fyrir innlögn á gjörgæslu en pær hafa breyst með árunum. Pannig eru nær eingöngu lagðir inn á gjörgæsludeild Landspítala sjúklingar sem parfnast vöktunar og meðferðar sem eingöngu er veitt á gjörgæsludeild, en hinir fara í gegnum vöknunardeild og paðan á legudeild.

Fækkun gjörgæsluinnlagna stuðlar að pví að halda niðri kostnaði tengdum aðgerðunum. Pessi próun verður að teljast jákvæð par sem sólarhringur á gjörgæsludeild er talsvert dýrari en á legudeild. Auk pess er fjöldi gjörgæsluplássa takmarkaður á sama tíma og skurðaðgerðum vegna lungnakrabbameins hefur fjölgað, bæði vegna fjölgunar tilfella en einnig vegna pess að sífellt eldri og veikari sjúklingar eru teknir í aðgerð.,5,16

Einungis 10 sjúklingar (4\%) purftu að leggjast á gjörgæsludeild af vöknunardeild eða legudeild allt rannsóknartímabilið, sem verður að teljast lágt hlutfall. Í fjórum tilfellum var lágur blóð- prýstingur ástæða gjörgæsluinnlagnar en prír pessara sjúklinga höfðu fengið utanbastsdeyfingu. Ekki reyndist pó munur á hlutfalli sjúklinga með utanbastsdeyfingu í gjörgæsluhópi og viðmiðunarhópi. Hins vegar reyndust bæði hár aldur og saga um langvinna lungnateppu spá fyrir um líkur pess að sjúklingar lögðust á gjörgæsludeild. Petta er í samræmi við nýlega rannsókn ${ }^{12}$ par sem útbúið var áhættulíkan fyrir innlögn á gjörgæsludeild. Par reyndust hár aldur, áætlað FEV1 eftir aðgerð $<65 \%$, loftdreifipróf (DLCO) $<50 \%$ og hjarta- og æðasjúkdómar vera helstu áhættupæettir innlagnar.

Ekki er til alpjóðlega viðurkennt spálíkan sem segir til um áhættu sjúklinga fyrir lungnaskurðaðgerð, líkt og EuroSCOREáhættulíkanið fyrir opnar hjartaaðgerðir. ${ }^{17}$ Í erlendum rannsóknum eru helstu áhættupættir skurðdauða eftir lungnaskurðaðgerð lágt FEV1-gildi, hár aldur og saga um lungnateppu og kransæðasjúkdóm. ${ }^{18,19}$ Í rannsókn Pieretti og félaga spáði tegund aðgerðar, hár ASA-flokkur, skert lungnastarfsemi og saga um aðra alvarlega sjúkdóma fyrir um líkur á innlögn á gjörgæsludeild. ${ }^{20}$

Dánartíðni innan 30 daga reyndist lág, eða 0,8\%. Petta er lægra en í flestum erlendum rannsóknum par sem hún er oftast á bilinu 0,6-4\% fyrir blaðnám og fleyg- eða geiraskurði. ${ }^{21,22}$ Lág dánartíðni gefur til kynna að snemmkominn árangur pessara aðgerða sé góður á Landspítala.

Eins og búast mátti við reyndust bæði alvarlegir og minniháttar fylgikvillar algengari hjá gjörgæslusjúklingum en í viðmiðunarhópi. Petta kemur ekki á óvart par sem alvarlegur fylgikvilli á borð við hjarta- og öndunarbilun eða blæðingu var oft ástæða innlagnar á gjörgæsludeild. Langvarandi loftleki ( $>7$ daga) var algengasti fylgikvillinn í báðum hópum en hann krefst brjóstholskera sem eykur verki og lengir legutíma. Gáttatif og lungnabólga voru einnig algeng í báðum hópum. Af alvarlegum fylgikvillum voru blæðingar algengastar. Oftast blæddi frá lungnaslagæð eða lungnabláæð og purftu 7 sjúklinganna að fara í enduraðgerð til pess að stöðva blæðinguna.

Flestum sjúklingum sem lögðust á gjörgæsludeild farnaðist vel eftir útskrift, en aðeins prír sjúklingar af 21 purftu á endurinnlögn að halda. Einn pessara sjúklinga lést á gjörgæsludeild en annar í sömu spítalalegu.

Styrkur pessarar rannsóknar er að hún nær til allra sjúklinga sem gengust undir blaðnám, fleyg- og geiraskurði á 10 ára tímabili. Stuðst var við ítarlegan gagnagrunn hjarta- og lungnaskurðdeildar Landspítala en par eru skráðar allar lungnaskurðaðgerðir sem framkvæmdar hafa verið við lungnakrabbameini á Íslandi síðastliðna tvo áratugi. Hins vegar er veikleiki rannsóknarinnar sá að stuðst var afturvirkt við upplýsingar úr sjúkraskrám, til dæmis hvað varðar ástæður fyrir innlögn á gjörgæslu. Í sumum tilvikum reyndist skráning innlagnarástæðu ófullkomin, en dagálar á gjörgæsludeild voru jafnan nákvæmir og skipulega færðir. Annað sem veikir rannsóknina er að sjúklingar sem lögðust á gjörgæsludeild purftu ekki allir sérhæfða gjörgæslumeðferð og í peim tilvikum virðist hafa verið um lengda vöktun að ræða.

Aðeins lögðust $8 \%$ sjúklinga á gjörgæsludeild eftir lungnaskurðaðgerð við lungnakrabbameini (lungnabrottnám undanskilin) og reyndust hærri aldur og saga um langvinna lungnateppu sjálfstæðir áhættupættir fyrir innlögn pangað. 


\section{Pakkir}

Pakkir fá Gunnhildur Jóhannsdóttir skrifstofustjóra og starfsfólk skjalageymslu Landspítala í Vesturhlíð fyrir aðstoð við að afla

sjúkraskráa. Loks fær Axel F. Sigurðsson hjartalæknir pakkir fyrir yfirlestur og góðar ábendingar.

\section{Heimildir}

1. Foley M. Cancer Screening and Diagnostics (lab manual) 2011, Reykjavik.

2. Scott WJ, Howington J, Feigenberg S, Movsas B, Pisters K. Treatment of non-small cell lung cancer stage I and stage II: ACCP evidence-based clinical practice guidelines (2nd edition). Chest 2007; 132 ( 3 Suppl): 234S-242S

3. Wahbah M, Boroumand N, Castro C, El-Zeky F, Eltorky M Changing trends in the distribution of the histologic types of lung cancer: a review of 4,439 cases. Ann Diagn Pathol 2007; 11: 89-96.

4. Skuladottir R, Oskarsdottir GN, Isaksson HJ, Jonsson S, Thorsteinsson H, Gudbjartsson T. Fylgikvillar blaðnámsaðgerða við lungnakrabbameini á Íslandi 1999-2008. Læknablaðið 2010; 96: 243-9.

5. Thorsteinsson $\mathrm{H}$, Jonsson $\mathrm{S}$, Alfreðsson $\mathrm{H}$, Isaksson $\mathrm{HJ}$ Gudbjartsson T. Árangur lungnabrottnámsaðgerða viðð lungnakrabbameini á Íslandi. Læknablaðið 2009; 95: 823-9.

6. Oskarsdottir GN, Skuladottir R, Isaksson HJ, Jonsson S, Thorsteinsson H, Gudbjartsson T. Forspárpættir lífshorfa eftir blaðnám við lungnakrabbameini á Íslandi 1999-2008. Læknablaðið 2010; 96: 251-7.

7. Gottschalk A, Cohen SP, Yang S, Ochroch EA. Preventing and treating pain after thoracic surgery. Anesthesiology 2006; 104: 594-600

8. Wenk M, Schug SA. Perioperative pain management after thoracotomy. Curr Opin Anaesthesiol 2011; 24: 8-12.
9. De Cosmo G, Aceto P, Gualtieri E, Congedo E. Analgesia in thoracic surgery: review. Minerva Anestesiol 2009; 75 393-400.

10. Dripps RD, Lamont A, Eckenhoff JE. The role of anesthesia in surgical mortality. JAMA. Oct 21 1961;178: 261-6.

11. Tsim S, O’Dowd CA, Milroy R, Davidson S. Staging of non-small cell lung cancer (NSCLC): a review. Respir Med 2010; $104: 1767-74$

12. Brunelli A, Ferguson MK, Rocco G, Pieretti P, Vigneswaran WT, Morgan-Hughes NJ, et al. A scoring system predicting the risk for intensive care unit admission for complication after major lung resection: a multicenter analysis. Ann Thorac Surg 2008; 86: 213-8.

13. Okiror L, Patel N, Kho P, Ladas G, Dusmet M, Jordan S, et al. Predicting risk of intensive care unit admission after resection for non-small cell lung cancer: a validation study. Interact Cardiovasc Thorac Surg 2012; 14: 31-3.

14. Axelsson TA. Innlagnir á gjörgæslu eftir skurðaðgerðir viðð lungnakrabbameini. BS-ritgerð, Háskóli Íslands 2011.

15. Balduyck B, Hendriks J, Lauwers P, Van Schil P. Quality of life evolution after lung cancer surgery: a prospective study in 100 patients. Lung Cancer 2007; 56: 423-31.

16. Alexandersson A, Jonsson S, Isaksson HJ, Gudbjartsson T. Árangur fleyg- og geiraskurða við lungnakrabbameini Íslandi. Læknablaðið 2011; 97: 304-8.
17. Nashef SA, Roques F, Michel P, Gauducheau E, Lemeshow $\mathrm{S}$, Salamon R. European system for cardiac operative risk evaluation (EuroSCORE). Eur J Cardiothorac Surg 1999; 16: 9-13.

18. Licker MJ, Widikker I, Robert J, et al. Operative mortality and respiratory complications after lung resection for cancer: impact of chronic obstructive pulmonary disease and time trends. Ann Thorac Surg 2006; 81: 1830-7.

19. Berrisford R, Brunelli A, Rocco G, Treasure T, Utley M. The European Thoracic Surgery Database project: modelling the risk of in-hospital death following lung resection. Eur J Cardiothorac Surg 2005; 28: 306-11.

20. Pieretti P, Alifano M, Roche N, Vincenzi M, Forti Parri SN, Zackova M, et al. Predictors of an appropriate admission to an ICU after a major pulmonary resection. Respiration 2006; 73: 157-65.

21. Harpole DH Jr, DeCamp MM Jr, Daley J, Hur K, Oprian CA, Henderson WG, et al. Prognostic models of thirty-day mortality and morbidity after major pulmonary resection. J Thorac Cardiovasc Surg 1999; 117: 969-79.

22. Myrdal G, Gustafsson G, Lambe M, Horte LG, Stahle E. Outcome after lung cancer surgery. Factors predicting early mortality and major morbidity. Eur J Cardiothorac Surg 2001; 20: 694-6.

ENGLISH SUMMARY

\section{Intensive care unit admissions following lobectomy or sublobar resections for non-small cell lung cancer}

Axelsson TA, Sigurdsson MI, Alexandersson A, Thorsteinsson H, Klemenzson G, Jonsson S, Gudbjartsson T

Introduction: Following resection for non-small cell lung cancer (NSCLC), patients are usually admitted to the post-anesthesia care unit (PACU)for a few hours before admission to a general ward (GW). However, some patients need ICU-admission, either immediately postsurgery or from the PACU or GW. The aim of this study was to investigate the indications and risk factors for ICU-admission.

Material and methods: A retrospective study of 252 patients who underwent lobectomy, wedge resection or segmentectomy for NSCLC in Iceland during 2001-2010. Data was retrieved from medical records and patients admitted to the ICU compared to patients not admitted. Results: Altogether 21 patients (8\%) were admitted to the ICU, median length-of-stay being one day (range 1-68). In 11 cases (52\%) the reasons for admission were intraoperative problems, usually hypotension or excessive bleeding. Ten patients were admitted from the $G W(n=4)$ or
PACU $(n=6)$, due to hypotension $(n=4)$, heart and/or respiratory failure $(n=4)$ and reoperation for bleeding $(n=2)$. There were three ICU-readmissions. Patients admitted to the ICU were six years older $(p=0.004)$ and more often had chronic obstructive pulmonary disease and/or coronary artery disease. Tumor size, pTNM-stage, length of operation and the ratio of patients receiving TEA (thoracic epidural anaesthesia) were similar between groups. Over two-thirds of the ICU-patients had minor complications and around half had major complications, compared to $30 \%$ and $4 \%$, respectively, for controls.

Conclusion: ICU-admissions are infrequent following non-pneumonectomy lung resections for NSCLC, these patients being older with cardiopulmonary comorbidities. In half of the cases, admission to the ICU directly follows surgery and ICU-readmissions are few.

Key words: Intensive care, post-anesthesia care unit, lung cancer, operation, thoracotomy, readmission, complications.

Correspondence: Tómas Guðbjartsson, tomasgud@landspitali.is

Faculty of Medicine, University of Iceland, Departments of Cardiothoracic Surgery, Anesthesia and Intensive Care and Pulmonology 